\title{
Carbon- and Oxygen-isotope Stratigraphy: A Tool for Confirming Sequence Stratigraphy in the Early Triassic Kangan Formation, Northern Part of the Arabian Plate
}

Fadi H. Nader (IFP, < fadi-henri.nader@ifpenergiesnouvelles.fr>), Hossain Rahim PourBonab (University of Tehran, Iran, <rahimpor@khayam.ut.ac.ir>), Mohammd Reza Kamali (Research Institute of Petroleum Industry, Iran, <kamalimr@ripi.ir >) and Maryam Peyravi

(Islamic Azad University, Iran, <mpeyravi@gmail.com>)

\begin{abstract}
Summary
The Early Triassic Kangan Formation, which is equivalent to the Upper Khuff Formation, is the main reservoir for natural gas in southwest Iran and the northern Gulf. Investigations of this formation in offshore "Field A" indicate that it is composed of 14 facies deposited in tidal flat, lagoon and oolitic barrier settings in the inner part of a carbonate ramp or platform. Vertical variations of microfacies and gamma-ray, log profiles show that the formation consists of three depositional sequences (KG1 to KG3), each consisting of transgressive and highstand systems tracts and each bounded above by a Type- 2 unconformity. Carbon- and oxygen-isotope profiles from a well-dated carbonate section were compared to sedimentological data and the results from a sequence-stratigraphic study. The profiles showed negative and positive peaks coinciding with sequence boundaries and maximum flooding surfaces, respectively.
\end{abstract}

\section{Introduction}

The Early Triassic Kangan Formation comprises one of the most important carbonate reservoir rocks in southwest Iran. The Kangan and underlying Dalan formations form the Deh Ram Group (Stratigraphic Committee of Iran, 1976). The two formations were discussed in detailed in a regional-scale account by Insalaco et al. (2006). Rahimpour-Bonab et al. (2010) investigated the reservoir quality of the formations in the South Pars gas field based on petrography, stable-isotope measurements, scanning electron microscope (SEM) analyses, and X-ray and CT scans of core samples. Peyravi et al. (2010) investigated the sedimentary environments, and sequence stratigraphy of the Kangan Formation in the northern part of the Gulf, emphasizing the implications for reservoir characterization based on petrography, gamma-ray $\log$, Cyclolog ${ }^{\circledR}$ software and Gunter's Technique. This present contribution shows that carbon- and oxygen-isotope signals can be used as a tool for confirmation of the sequence-stratigraphic surfaces.

\section{Geological Setting}

The Kangan Formation is the main reservoir in the offshore Field A, located $140 \mathrm{~km}$ south of Lavan Island offshore southern Iran (Figure 1). The formation is correlative with the upper part of the Khuff Formation to the south (Alsharhan, 1993; Al-Jallal, 1995; Kashfi, 2000, Fontana et al., 2010). In the study area, the Kangan Formation is composed of dolomites, evaporites, limestones and shales with an overall thickness of $390 \mathrm{~m}$. At its type section, the Kangan rests conformably on the Dalan Formation (Motiei, 1993) and is conformably overlain by the Aghar Shale, part of the Dashtak Formation (Szabo and Kheradpir, 1978). Several authors have suggested that Late Silurian organic-rich shales, known in Iran as the Sarchahan Formation and in Saudi Arabia as the Qusaiba "hot shales", represent the source rock for the hydrocarbons in Permian and Lower Triassic reservoirs (e.g. Bordenave, 2008; Ameen et al., 2010; Rahimpour et al., 2010). In Iran, the Sarchahan Formation is sealed by the thick, massive anhydrites of the Middle to Late Triassic Dashtak Formation (Bordenave, 2008; Rahimpour et al., 2010). 


\section{Material and Methods}

This research is based on petrographic studies of 270 thin sections obtained from cores from Field A, as well as sedimentological interpretations of gamma-ray logs. Thin sections were treated with Alizarin Red-S following Dickson (1966). Carbonate rocks were classified following Dunham (1962). Facies analysis and vertical and lateral changes were recorded following Carrozzi (1989) and Flügel (2004). Sequence-stratigraphic interpretations followed Van Wagoner (1988), Tucker (1999), Emery and Myers (1996), Miall (1997, 2000) and Catuneanu (2002). 44 samples were selected for carbon and oxygen stable-isotope analyses $\left(\delta^{13} \mathrm{C}\right.$ and $\left.\delta^{18} \mathrm{O}\right)$.

Considering the sequence-stratigraphic surfaces and framework, and homogeneity, 41 samples from well core slabs were microdrilled while four samples were obtained by computer-automated micromill (IFP Energies nouvelles - Petrography Laboratory). Analyses carried out at the Department of Geology, University of Erlangen, Germany. Carbonate powders were reacted with $100 \%$ phosphoric acid at $75^{\circ} \mathrm{C}$ using a Kiel 111 carbonate preparation line connected online to a Thermo Finnigan 252 mass spectrometer. All values are reported in permil relative to V-PDB by assuming a $\delta^{13} \mathrm{C}$ value of $+1.95 \%$ and $\delta^{18} \mathrm{O}$ of $2.20 \%$ to NSB19. Oxygen-isotope values of dolomite were corrected using the phosphoric acid fractionation factor given by Rosenbaum and Sheppard (1986) and Kim et al (2007).

\section{Results and Discussion}

From petrographic observations of the Kangan Formation and gamma-ray logs, 14 microfacies were identified and were grouped into three facies associations: (1) tidal flat, (2) lagoonal, and (3) barrier. Equivalent facies were recognized by Insalaco et al. (2006) and Moradpour et al. (2008). These facies were deposited in the inner part of the carbonate ramp platform (Insalaco et al., 2006; Rahimpour et al., 2010; Peyravi et al., 2010).

1)The tidal flat facies association consists of facies interpreted as originating in the intertidal and supratidal zone. It includes facies (A1), layered anhydrites with chickenwire texture; (A2) fenestral dolomudstones and stromatolite-thrombolite boundstones; and (A3) dolomudstones with evaporite casts and peloid grainstones with keystone vugs.

2)The lagoonal facies association contains facies (B1): peloid grainstones and bioclast peloid packstone-grainstones; (B2) bioclast wackestones and bioturbated dolomitized lime mudstone/mudstones; and (B3) shale.

3) The barrier facies association includes: $(\mathrm{C} 1)$ ooid peloid grainstones and dolomitized ooid packstone/grainstones; (C2) dolomitized bioclastic oolitic intraclast packstone/ grainstones; and (C3) dolomitized intraclastic/ oolitic bioclastgrainstones.

Vertical facies variations in the Kangan Formation in Field A led to the recognition of three unconformity-bound sequences (KG3, KG2 and KG1). These sequences are comparable to the Lower Triassic part of the Permian-Triassic Ashk Supersequence of Heydari (2008).

Carbon- and oxygen-isotope profiles from a well-dated carbonate section from the Kangan Formation were compared to the sedimentological data and the results from sequencestratigraphic analysis, in order to discuss the origin of isotopic variations in a shallow-marine carbonate succession. Our study led to the recognition of three third-order cycles whose boundaries correspond to distinct $\delta^{13} \mathrm{C}$ and $\delta^{18} \mathrm{O}$ negative peaks (Figure 2).

\section{Conclusions}

A study of lateral and vertical facies changes of the Kangan Formation in offshore southern Iran indicates that the formation was deposited in the inner part of a carbonate ramp/platform. 
The Kangan Formation comprises three depositional sequences, from oldest to youngest: $\mathrm{KG} 3, \mathrm{KG} 2$ and KG1. The lower boundary of KG3 forms a correlative conformity rather than an unconformity due to its palaeo-depositional setting. Isotopic data validated the sequence stratigraphy based on facies analysis; boundaries of the third-order cycles correspond with depleted isotopic compositions; and maximum flooding surfaces are marked by enriched isotopic compositions which is validated.

\section{References}

Al-Jallal, I.A. 1995. The Khuff Formation: Its regional reservoir potential in Saudi Arabia and other Gulf countries; depositional and stratigraphic approach. In M.I. Al-Huseini (Ed.), Middle East Petroleum Geosciences Conference, GEO’94. Gulf PetroLink, Bahrain, v. 1, p. 103-119.

Alsharhan, A.S. 1993. Facies and sedimentary environment of the Permian carbonates (Khuff Formation) in the United Arab Emirates. Sedimentary Geology, v. 84, p. 89-99.

Ameen, M.S., I.M. Buhidma and Z. Rahim 2010. The function of fractures and in-situ stress in the Khuff Reservoir performance, onshore fields, Saudi Arabia. AAPG Bull, v. 94, p. 27-60.

Bordenave, M.L. 2008. The origin of the Permo-Triassic gas accumulations in the Iranian Zagros fold belt and contiguous offshore areas: A review of the Palaeozoic petroleum system. Journal of Petroleum Geology, v. 31, no. 1, p. 3-42.

Carozzi, A.V. 1989. Carbonate rock depositional models: a microfacies approach. Prentice Hall, 604p.

Catuneanu, O. 2002. Sequence of clastic systems concepts merits and pitfalls. Journal of African Earth Science, v. 35, p. 1-43.

Dickson, J.A.D. 1966. Carbonate identification and genesis as revealed by staining. Journal of Sedimentary Petrology, v. 36, p. 491-505.

Dunham, R.J. 1962. Classification of carbonate rocks according to depositional texture. In W.E. Hamm (Ed.), Classification of Carbonate Rocks, A Symposium. AAPG, p. 108-121.

Emery, D. and K.J. Myers 1996. Sequence stratigraphy. Blackwell Science, Oxford, 297 p.

Flugel, E. 2004. Microfacies of carbonate rocks analysis, interpretation and application. Springer-Verlag, Berlin, $976 \mathrm{p}$.

Fontana, S., F.H. Nader, S. Morad, A. Ceriani and I.S. Al-Aasm 2010. Diagenesis of the Khuff Formation (Permian-Triassic) northern United Arab Emirates. Arabian Journal of Geosciences, v. 6, p. 351-368.

Heydari, E. 2008. Tectonics versus eustatic control on supersequences of the Zagros Mountains of Iran. Tectonophysics, v. 451, p. 56-70.

Insalaco, E., A. Virgon, B. Courme, J. Gaillot, M. Kamali, A. Moallemi, M. Lotfpour and S. Monibi 2006. Upper Dalan Member and Kangan Formation between the Zagros Mountains and offshore Fars, Iran: Depositional system, biostratigraphy and stratigraphic architecture. GeoArabia, v. 11, no. 2, p. 75-176.

Kashfi, M.S. 2000. The greater Persian Gulf Permian - Triassic stratigraphic nomenclature requires study. Oil and Gas Journal, no. 6, p. 36-44.

Kim, S.T., A. Mucci and B.E. Taylor 2007. Phosphoric acid fractionation factors for calcite and aragonite between 25 and $75^{\circ} \mathrm{C}$ : Revisited. Chemical Geology, v. 246, p. 135-146.

Miall, A.D. 1997. The Geology of Stratigraphic Sequences, Springer-Verlag, Berlin, 433 p.

Miall, A.D. 2000. Principals of Sedimentary Basin Analysis, Springer-Verlag, Berlin, 616 p.

Moradpour, M., Z. Zamani and S.A. Moallemi 2008. Controls on the reservoir quality in the lower Triassic Kangan Formation, southern Persian Gulf. Journal of Petroleum Geology, v. 31, no. 4, p. 367-385.

Motiei, H. 1993. Stratigraphy of Zagros. Geological Survey of Iran, Treatise on the Geology of Iran no. $1,536 \mathrm{p}$.

Peyravi, M., M.R. Kamali and M. Kalani 2010. Depositional environments and sequence stratigraphy of the Early Triassic Kangan Formation, in the northern part of the Persian 
Gulf: implications for reservoir characteristics. Journal of Petroleum Geology, v. 33, no. 4, p. 371-386.

Rahimpour-Bonab, H., B. Esrafili-Dizaji and V. Tavakoli 2010. Dolomitization and anhydrite precipitation in Permo-Triassic carbonates at the South Pars Gas Field, Offshore Iran: controls on Reservoir quality. Journal of Petroleum Geology, v. 33, no. 2, p. 1-24

Rosenbaum, J. and S.M.F. Sheppard 1986. An isotopic study of siderites, dolomites and ankerites at high temperatures. Geochimica et Cosmochimica Acta, v. 50, no. 6, p. 11471150.

Stratigraphic committee of Iran 1976. Permo-Triassic rock stratigraphic nomenclature in south Iran. Unpublished report, Tehran.

van Wagoner, J.C., H.W. Posamentier, R.M. Mitchum, P.R. Vail, J.F. Sarg, T.S. Loutit and J. Hardenboll 1988. An overview of the fundamentals of sequence stratigraphy and key definitions. In C.K. Wilgus, B.S. Hastings, C.G.St.C. Kendall, H.W. Posamentier, C.A. Ross, and J.C. van Wagoner (Eds.), Sea-level Changes: An Integrated Approach. Society of Economic Paleontologists and Mineralogists, Special Publication no. 42, p. 39-45.

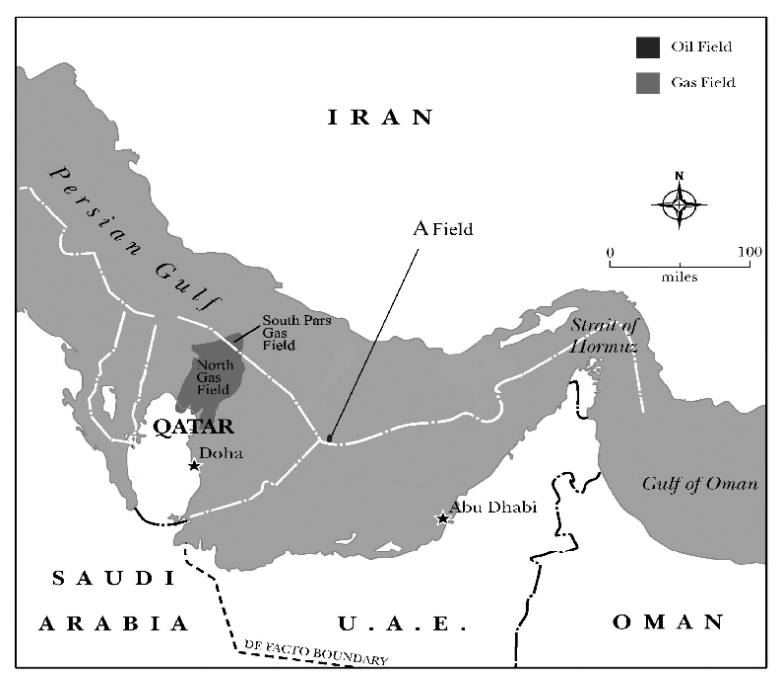

Figure 1: Location map of the study area and approximate position of the studied sections offshore southern Iran (modified after Peyravi et al., 2010). 


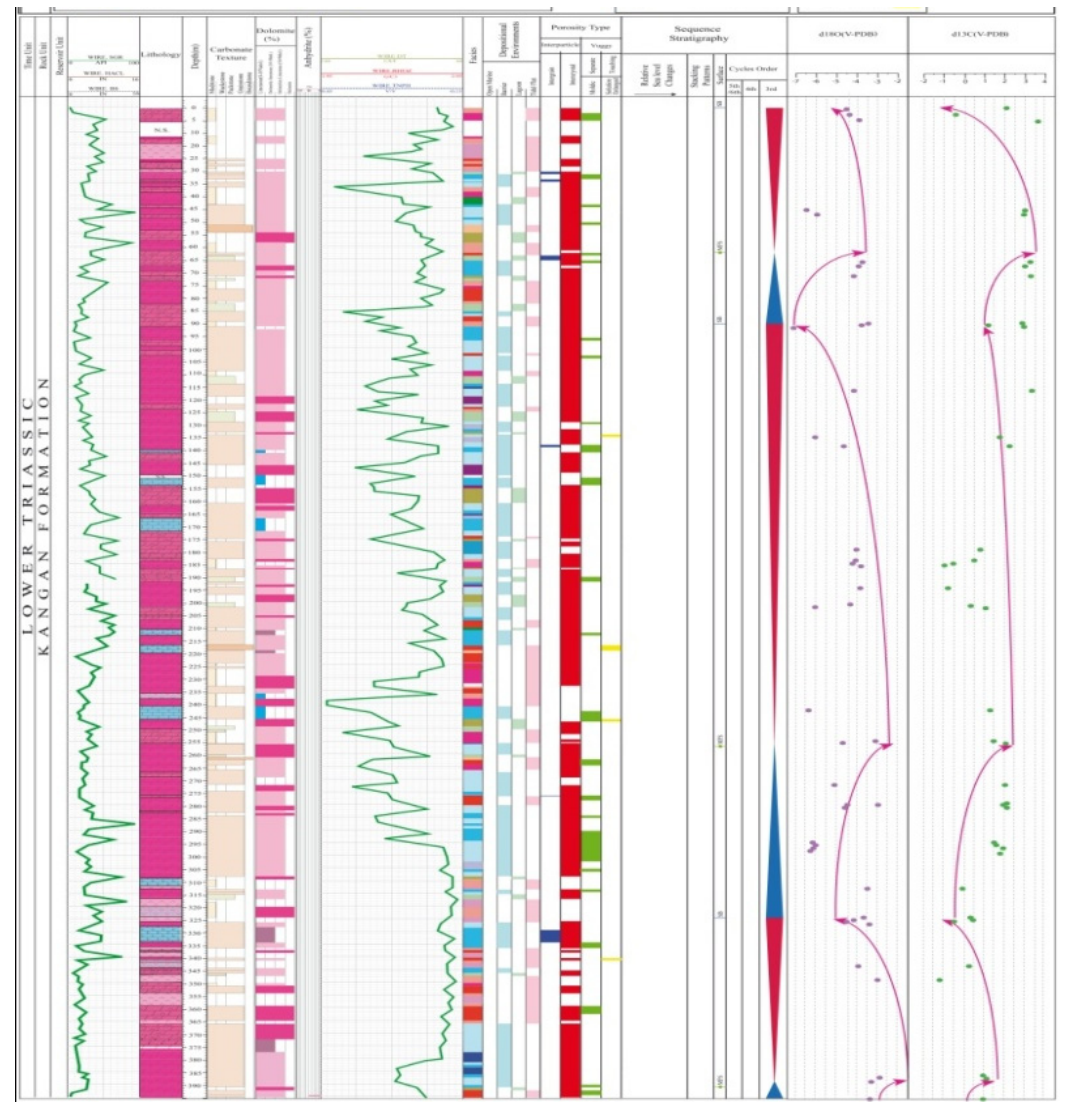

Figure 2: Lithological column, facies, sequence stratigraphy, gamma-ray log, and carbonand oxygen-isotope profiles from the studied area. 